\title{
Epigenetic Mechanisms in Gastric Cancer: Potential New Therapeutic Opportunities
}

\author{
Matteo Canale ${ }^{1}{ }^{\circledR}$, Andrea Casadei-Gardini ${ }^{2, *}$, Paola Ulivi ${ }^{1}$, Maria Arechederra ${ }^{3,4}{ }^{\circledR}$, \\ Carmen Berasain ${ }^{3,4,5} \mathbb{D}$, Pier-Luigi Lollini ${ }^{6} \mathbb{D}$, Maite G. Fernández-Barrena ${ }^{3,4,5} \mathbb{D}$ \\ and Matías A. Avila $3,4,5, *$ iD \\ 1 Biosciences Laboratory, Istituto Scientifico Romagnolo per lo Studio e la Cura dei Tumori (IRST) IRCCS, \\ 47014 Meldola, Italy; matteo.canale@irst.emr.it (M.C.); paola.ulivi@irst.emr.it (P.U.) \\ 2 Department of Oncology and Hematology, Division of Oncology, University of Modena and Reggio Emilia, \\ 41125 Modena, Italy \\ 3 Program of Hepatology, Center for Applied Medical Research (CIMA), University of Navarra, \\ 31008 Pamplona, Spain; macalderon@unav.es (M.A.); cberasain@unav.es (C.B.); \\ magarfer@unav.es (M.G.F.-B.) \\ 4 IdiSNA, Navarra Institute for Health Research, 31008 Pamplona, Spain \\ 5 National Institute for the Study of Liver and Gastrointestinal Diseases (CIBERehd, \\ Carlos III Health Institute), 28029 Madrid, Spain \\ 6 Laboratory of Immunology and Biology of Metastasis, Department of Experimental, Diagnostic \\ and Specialty Medicine (DIMES), University of Bologna, 40126 Bologna, Italy; pierluigi.lollini@unibo.it \\ * Correspondence: casadeigardini@gmail.com (A.C.-G.); maavila@unav.es (M.A.A.)
}

Received: 26 June 2020; Accepted: 29 July 2020; Published: 31 July 2020

check for updates

\begin{abstract}
Gastric cancer (GC) is one of the deadliest malignancies worldwide. Complex disease heterogeneity, late diagnosis, and suboptimal therapies result in the poor prognosis of patients. Besides genetic alterations and environmental factors, it has been demonstrated that alterations of the epigenetic machinery guide cancer onset and progression, representing a hallmark of gastric malignancies. Moreover, epigenetic mechanisms undergo an intricate crosstalk, and distinct epigenomic profiles can be shaped under different microenvironmental contexts. In this scenario, targeting epigenetic mechanisms could be an interesting therapeutic strategy to overcome gastric cancer heterogeneity, and the efforts conducted to date are delivering promising results. In this review, we summarize the key epigenetic events involved in gastric cancer development. We conclude with a discussion of new promising epigenetic strategies for gastric cancer treatment.
\end{abstract}

Keywords: gastric cancer; epigenetic mechanisms; epigenetic therapies

\section{Introduction}

Gastric cancer (GC) represents one of the most challenging issues for medical oncology, with 1 million people affected worldwide and patient 5-year survival rates ranging from 5 to $69 \%$, depending on the stage of the disease at diagnosis [1,2]. Incidence and mortality rates are highly variable by region, as Eastern countries register higher morbidities. GC is influenced by several risk factors such as diet, active tobacco smoking, and Helicobacter pylori infections, recognized as the main risk factor for about $90 \%$ of newly diagnosed non-cardia gastric cancers [3,4]. The disease is characterized by a wide heterogeneity at the histopathological, onset location, and molecular levels, resulting in a complex scenario for patients' clinical management and prognosis. Current treatment algorithms for GC are not able to effectively face this heterogeneity, thus creating a need for precision medicine strategies. Regarding genetic features, gastric cancers are defined by remarkable epigenetic alterations playing an active role both at the early stages of carcinogenesis and in the advanced disease. Several studies have 
highlighted the role of epigenetic dysregulation in GC onset and progression, in particular focusing on which driver epigenetic mechanisms could be targeted as a therapeutic approach for GC treatment $[5,6]$. Despite this, to date no epigenetic therapies are available for GC clinical management, and given the importance of the gastric epigenome as a main point for molecular pathogenesis and progression, effective epigenetic treatments could open a new landscape for management of the disease.

\section{Gastric Cancer}

GC is the 3rd most diagnosed and the 5th deadliest malignancy worldwide, accounting for 1 in every 12 cancer-related deaths [1]. Even though the majority of GCs are histologically classified as adenocarcinomas, GC is a heterogeneous disease that presents through different phenotypes, growth patterns, anatomic locations, and molecular characteristics, and therefore different classification systems have been proposed.

\subsection{Anatomical, Histological, and Molecular Classification of Gastric Cancer}

Gastric carcinogenesis is triggered by the interaction of different risk factors, and emerges through sequential histopathologic stages, including chronic gastritis, atrophic gastritis, intestinal metaplasia, dysplasia, and cancer $[7,8]$. As other luminal gastrointestinal organs, stomach cells undergo a rapid and continuous turnover, with the multipotent stem cells residing at the top of the renewal pyramid and governing organ homeostasis [9]. Hence, for their longevity and self-renewal properties, it has been suggested that gastric stem cells could represent the GC cells of origin, being ideal targets for the accumulation of genetic alterations and field cancerization, and the expansion of pro-tumorigenic mutant clones $[9,10]$. Interestingly, it has been highlighted that pre-cancerous lesions are characterized by a distinctive epigenetic field cancerization, mainly influenced by $H$. pylori infection [11,12].

Classification based on cancer anatomical location identifies cardia (gastroesophageal junction) and non-cardia (true gastric) tumors, which also differ in terms of incidence, regional distribution, treatment, and prognosis [13]. Cardia GCs following the Siewert classification consist of three types of cardia cancers (Siewert type I, II, or III) on the basis of the location of the epicenter of tumor with respect to gastroesophageal junction [14]. More recently, Tumor-node-metastasis (TNM) staging stystem introduced further parameters to identify gastroesophageal carcinomas, taking into account the tumor epicenter and the location where the tumor mass extends [15].

The Lauren classification, based on histological features, divides GCs into diffuse-, intestinal-, and mixed type, depending on tissue architecture and glandular patterns. Diffuse-type identifies non-cohesive and poorly differentiated tumors, with no gland formation, while intestinal-type tumors are moderate to differentiated tumors, with glandular structure not strictly related to a specific risk factor. Mixed type presents intermediate or characteristics from both previous types [16].

The successive WHO classification identifies five GC subtypes, mainly depending on the histological patterns of the tumor, that is, tubular, papillary, mucinous, and poorly cohesive subtypes and rare variants have been identified. Tubular carcinomas are characterized by low- to high-grade nuclear atypia with poorly differentiated cancer cells, distinguished from the papillary subtype that presents with finger-like processes of cuboidal or cylindrical cells. Mucinous carcinomas are so classified with the identification of 50\% extracellular mucin, while poorly cohesive tumors have cancer cells alone or organized in small aggregates; this subtype includes signet-ring cells tumors. The mixed tumors, as their name implies, include a heterogeneous mix of the previous subtypes [17]. This classification sometimes overlaps with the one proposed by Lauren (tubular and papillary subtypes correspond to intestinal-type, poorly cohesive is associable to diffuse-type), and very often different subtypes coexist in a single tumor, although in different percentages; it is thus difficult to classify them into exclusive subtypes.

The Cancer Genome Atlas (TCGA) program proposed the first molecular approach for GC classification. Genomic profiling of 295 primary gastric adenocarcinomas identified 9\% of Epstein-Barr virus (EBV) positive tumors, $22 \%$ of microsatellite unstable, $20 \%$ of genomically stable, and $50 \%$ of 
chromosomally stable tumors [18]. Interestingly, these subgroups showed associations with histological subtypes and tumor locations, i.e., EBV positive tumors are mostly located in the fundus or body of the stomach, with higher prevalence in men ( $81 \%)$; chromosomally unstable adenocarcinomas are more frequent in the gastro-esophageal junction, whereas genomically stable tumors more often present with diffuse-type histology. Another classification based on transcriptome molecular signature identified four gastric cancer subtypes on the basis of clinically relevant features. Hypermutated tumors with microsatellite instability (MSI), characterized by intestinal subtype and major location within the antrum of the organ, showed the best prognosis and lower rates of recurrence. Microsatellite-stable (MSS) tumors were divided into mesenchymal subtype associated with worst clinical outcome and highest recurrence rates, and epithelial subtype showed intermediate prognosis. MSS epithelial tumors were further divided into MSS/TP53+ and MSS/TP53-, with a better prognosis identified in the former group [19].

\subsection{Gastric Cancer Clinical Management}

For early GC, surgery remains the best treatment option [20,21]. Total or partial gastrectomy are the most common surgical modalities, together with a lymphadenectomy [22]. Pre-, peri- and post-operative chemotherapy approaches are highlighted to improve the outcome of patients, since these treatments prolong the 5-year overall survival (OS) of patients of $10-15 \%$ [13].

Survival of patients with metastatic disease is very poor, ranging from 4 to 12 months $[23,24]$. A large set of cytotoxic compounds are commonly used for treatment of advanced GC, such as fluoropyrimidines, platinum-based agents, taxanes, epirubicin, and irinotecan. These were initially used as monotherapies, but randomized trials and a meta-analysis showed a benefit in survival achieved by combination chemotherapy [23]. To date, the most common cytotoxic strategy is the combination of a fluoropyrimidine with a platinum-based compound [25].

On the basis of the results of the Trastuzumab for Gastric Cancer (ToGA) trial, trastuzumab plus chemotherapy has been approved as a first-line therapy for patients carrying Her-2 amplification, showing a median overall survival (OS) of 13.8 vs. 11.1 for anti-Her2 plus CT and the CT arm, respectively [26]. To date, this is the only targeted therapy approved in first-line treatment for GC management, and in recently published results from a phase 2 trial, the conjugate trastuzumab deruxtecan led to significant improvement in response rates and OS in pre-treated GC patients [27]. However, this molecular targeted therapy is available only for patients with Her2 amplification/overexpression (no more than 20\% in frequency) [13]. The VEGFR-2 inhibitor ramucirumab, even though it did not confer survival benefit as a first-line treatment, was approved as a second-line treatment alone or in combination with paclitaxel, depending on the performance status of patients, on the basis of the results of the REGARD and RAINBOW trials [28,29]. Other precision medicine approaches have been attempted or are still under investigation, e.g., targeting of EGFR, VEGFR, FGFR, or the HGF receptor c-Met, but no significant improvements in OS of patients have been reached $[30,31]$.

Immunotherapeutic strategies for GC are still under investigation, with some interesting emerging indicators of evidence [32]. It was reported that PD-L1 expression is related to patient prognosis and response to immune checkpoint inhibitors (ICIs), and patients with EBV positive and MSI tumors could benefit from ICI treatment, for the increased number of neo-antigens and consequent immunogenicity [33]. However, none of these biomarkers has been validated, and results from large clinical trials are needed to confirm the use of immunotherapy as a therapeutic option for gastric cancer treatment.

\section{Epigenetics of GC}

Epigenetic alterations are recognized to be both early tumor-promoting and advanced-stage events in GC [34]. Environmental and genetic factors, such as diet, age, smoking, and chronic inflammation consequent to $H$. pylori and EBV infections, are able to remodel gastric epigenetic 
machinery, actively paving the way for gastritis and ulcer development until metaplasia, dysplasia, and tumor development [34]. Another study analyzed the mutation status of 55 cancer-related genes, and a total of 485,512 methylation spots (482,421 in CpG sites and 3091 in non-CpG sites), finding that epigenetic aberrations could affect many cancer-related pathways [35]. Thus, there is an increasing interest about GC epigenetic events, aiming to better understand GC physiopathology and, more importantly, to find relevant targets for translational medicine. In this context, recent investigations proposed new classifications of GCs based on different epigenetic profiles rather than on somatic alterations subtyping, identifying gene methylation panels able to predict the prognosis of patients and the risk of GC metastasis [36-38]. In this section, we discuss the main histone and DNA epigenetic modifications characterizing GC, while the role of non-coding RNAs and their potential therapeutic interest in gastrointestinal cancers have been recently reviewed elsewhere [39].

\subsection{DNA Methylation}

Repeated CG dinucleotide sequences, often found in CpG islands (CGIs), are located in the promoter region of half of the genes, playing a central role in gene expression regulation. Methylation occurring at the 5-position of cytosines within CpG dinucleotides is a reversible process catalyzed by DNA methyltransferases (DNMTs), resulting in the formation of 5-methylcytosine $(5 \mathrm{mC})$ and gene expression inhibition. The methylation process is reverted by ten-eleven translocation (TET) proteins, that demethylate DNA oxidizing 5-mC to 5-hydroxymethylcytosine (5-hC), and can re-activate gene expression $[40,41]$. Through the TCGA molecular characterization, two subgroups of tumors with high methylation levels at multiple loci emerged, both identified as $\mathrm{CpG}$ island methylator phenotype (CIMP). These subgroups showed distinct methylation profiles and belong to EBV-positive tumors and the MSI subtype, referred to as gastric CIMP $[18,42]$. As other malignancies, GCs present global genomic DNA hypomethylation accompanied by focal hypermethylation. Generally, global hypomethylation is responsible for proto-oncogene activation and genomic instability, whereas focal hypermethylation has been implicated in turning off tumor suppressor genes.

Loss of oncosuppressor CDH1 is a major feature of GC. Promoter hypermethylation, loss of heterozygosity (LOH), somatic mutations, and deletions affecting this gene have been related to both intestinal and diffuse GC, as well as germline mutations are considered to be the genetic cause of hereditary diffuse GC [43-45]. Interestingly, methylation of $C D H 1$ promoter has been found in $50 \%$ of hereditary diffuse GCs, and generally cooperates with genomic alterations, acting as a "second hit" to definitively silence the gene [43,46-48]. CDH1 encodes for the adhesion molecule E-cadherin, and its loss triggers cancer-related pathways such as $\beta$-catenin and Wnt-, EGFR-, and mTOR-dependent signaling cascades $[49,50]$. CDH1 hypermethylation is an early event in GC onset. It has been strictly related to $H$. pylori infection [51-53], and has also clinical significance, being able to predict worse (OS) and disease-free survival (DFS) of patients [54].

Important methylation-altered genes in GC are those involved in DNA mismatch repair (MMR) pathway. This process has a central role in maintaining the stability of the genome $[55,56]$, and its epigenetic deregulation has been highlighted in various tumors including sporadic GC, while gene mutations affecting the main genes of the process are considered the molecular fingerprint for hereditary gastric disorders (i.e., Lynch syndrome) [57]. Methylation of promoter regions of MLH1 and $M L H 2$ has been related to GC onset and progression in 108 GC specimens, and to chemoresistance to oxaliplatin [58]. Interestingly, methylation of $M L H 1$ predicted poor OS for advanced-stage GC patients, especially when combined with loss of oncosuppressor O(6)-methylguanine-DNA methyltransferase in two different cohorts of 135 and 68 GC patients (MGMT), while it was found to be a biomarker of better prognosis in resectable GC patients $[59,60]$. As expected, loss of $M L H 1$ is frequently observed in the gastric CIMP subgroup, having a strong relation with MSI tumors [18].

Several studies reported that aberrant methylation affects genes involved in cancer-related pathways able to influence the prognosis of GC patients. These include hypermethylation of RASSF1A, involved in cell cycle regulation, hypomethylation of $H R A S$, a component of RAS pathway [58,61,62], 
hypermethylation of the negative regulator of $\beta$-catenin/Wnt pathway DKK3 [63], and hypomethylation of proto-oncogene $c-M Y C$ [62].

The CDKN2A gene encodes for p16, that inhibits CDK, resulting in cell cycle arrest, and has often been found as target for promoter methylation in GC and other gastrointestinal and solid malignancies [64-66]. Moreover, methylation of the CDKN2A promoter was also found in gastric pre-cancerous lesions in association with $H$. pylori and EBV infections, demonstrating that it could be implicated in gastric carcinogenesis [67-69]. For these reasons, methylation of this gene has been investigated as a biomarker of the prediction of cancer development in 207 non-neoplastic patients and, together with $C D H 1$, was found to be a promising liquid biopsy biomarker for early cancer diagnosis and prognosis prediction [70-73].

Even though RUNX3 is not frequently mutated in GC, the loss of RUNX3 is involved in GC development [74]. The promoter region of this gene was found hypermethylated in most of the patients affected by GC (75 GC patients), with respect to cases of gastritis or non-neoplastic tissues (99 and 109, respectively) [75]. Key epigenetically deregulated genes in gastric cancer are reported in Table 1.

Table 1. Key epigenetically dysregulated genes in gastric cancer.

\begin{tabular}{ccc}
\hline Target & Role & Ref. \\
\hline CDH1 & Cell-cell adhesion & {$[47]$} \\
$M L H 1, M L H 2$ & DNA repair & {$[58]$} \\
$M G M T$ & DNA repair & {$[59]$} \\
$D K K 3$ & Wnt signaling pathway regulation & {$[63]$} \\
RADSSF1A & Cell cycle regulation & {$[61]$} \\
$H R A S$ & Component of RAS pathway & {$[62]$} \\
$C-M Y C$ & Transcription factor & {$[62]$} \\
$C D K N 2 A$ & Cell cycle regulation & {$[64]$} \\
RUNX3 & Transcription factor & {$[73]$} \\
$V E G F-c$ & Neo-angiogenesis related & {$[76]$} \\
GATA $4 / 5$ & Gastrointestinal cell differentiation & {$[76]$} \\
\hline
\end{tabular}

DNA methylation is an enzymatic reversible process catalyzed by a family of DNMTs. DNMT1 is responsible for maintaining the symmetrically methylated CGIs during DNA replication, with a role in genomic imprinting. DNMT3A and DNMT3B are able to act as de novo DNA methyl transferases, whereas DNMT2 has been identified as a tRNA methyltransferase [76-79]. DNMTs play a pivotal role in gene transcription regulation during normal development, and although expression itself does not necessarily mean increased functionality, aberrant DNMT expression has been related to carcinogenesis in almost all malignancies, including GC, as inactivation of several tumor suppressor genes occurs in a DNMT-dependent manner [80,81]. In a study by Yang et al., DNMTs were found highly expressed in GC tissue specimens (54 patients). Interestingly, DNMT1 expression correlated with cardia or body of the stomach localization of the tumor, DNMT3A expression correlated with TNM score, and their co-expression showed a correlation with lymph-node metastasis [82]. Mutze et al. found that low DNMT1 expression predicted better OS and clinical response in 127 patients treated with adjuvant therapy [83], and a comprehensive meta-analysis found that tumor tissues are characterized by high expression levels of DNMT1, with respect to normal, para-cancerous, and dysplastic tissues. Moreover, DNMT1 was found upregulated in stage III and IV patients, associated with GC risk and worse prognosis [84]. Accordingly, the TCGA molecular classification identified DNMT1 as the most upregulated among all DNMTs in each molecular subgroup [41], suggesting that it could be a common molecular driver for different pathogenesis patterns.

Other studies focused on the different DNMT gene polymorphisms, finding conflicting results about possible associations between specific a single-nucleotide polymorphism (SNP) and DNMT activity and prognosis of patients, [85-90], with the DNMT1 rs16999593 variant emerging as associated with enhanced risk of GC development in two different meta-analyses [91,92]. 
Multiple pathways in gastric carcinogenesis regulate DNMT expression. H. pylori and EBV infections result in chronic inflammation within the gastric mucosa, affecting epigenetic machinery and modulating DNMT expression through the release of oncogenic proteins such as CagA, and inflammatory responses mediated by tumor-associated macrophages (TAMs) [12,81]. Moreover, DNMT1 expression is regulated by the tumor suppressor APC through the downstream pathway APC $/ \beta$-catenin/TCF [93], and mutation or loss of APC may result in uncontrolled DNMT1 expression. Interestingly, while in colon cancers the $A P C$ gene is recurrently affected by somatic mutations, it has been found that $A P C$ promoter hypermethylation is a frequent event in GC patients, even though somatic mutations were also found in a small percentage of patients [94,95].

H. pylori, the only carcinogenic bacterium recognized by the WHO, triggers a series of inflammatory responses within the mucosal microenvironment, including the release of pro-inflammatory cytokines, such as IL-1, IL-6, IL-8, and TNF- $\alpha$, and the activation of the NF-KB pathway $[3,96,97]$. Moreover, phosphorylated bacterial protein CagA is able to interact with SH2-containing phosphatase (SHP-2), inducing cytoskeleton and morphological changes via inactivation of focal adhesion kinase (FAK), disturbing the tissue architecture and leading the so-called hummingbird phenotype, which is involved in gastritis patterns and cancer development $[98,99]$. The activation of such pathways leads to sustained chronic inflammation within the mucosal microenvironment, and several studies reported that $H$. pylori infection is able to actively shape a pro-oncogenic epigenetic profile, especially through a wide hypermethylation of tumor suppressor genes, i.e., those of the SWI/SNF family [100].

\subsection{Histone Modifications}

Histones are a family of evolutionarily highly conserved basic proteins, which organize in octamers to wrap DNA into nucleosomal structures. Nucleosomes are characterized by histones projecting their $\mathrm{N}$-terminal tails that can be post-translationally modified at single amino acid residues through different mechanisms. These include covalent modifications such as methylation, acetylation, phosphorylation, ribosylation, ubiquitination, and sumoylation [101,102] that are able to influence gene expression by changing chromatin accessibility to RNA polymerase II and transcription factors [103]. In this section, we discuss the two main histone modifications involved in gastric carcinogenesis which are also of interest for epigenetic therapeutic targeting, namely histone methylation and histone acetylation.

\subsubsection{Histone Methylation}

Methylation of histone tails largely occurs at lysine residues, which could be mono- (me1), di- (me2), or tri-methylated (me3). This reversible epigenetic mechanism is catalyzed by histone methyltransferases (HMTs) and reverted by histone demethylases (HDMs). Histone methylation plays a dual role in gene expression regulation because, depending on the specific amino acid residue and the number of methyl groups bound, this epigenetic mechanism leads to repression or activation of gene transcription [102]. Indeed, in histone H3, methylation at lysines H3K9 and H3K27 is associated with gene silencing, whereas methylation at H3K79 is associated with transcription activation [104]. DNA and histone methylation are paired and cooperating mechanisms, with DNMTs and HMTs involved in an intense crosstalk impacting on chromatin conformation and accessibility [105]. In fact, the H3K27 methylating enzyme EZH2 is able to recruit DNMTs and, vice versa, DNMT1 and DNMT3a are able to bind the H3K9 histone methyltransferase KMT1A. Moreover, it has been shown that DNA promoter regions enriched in H3K27me3 are hypermethylated in GC cell lines such as BGC-823 and AGS $[106,107]$. Similar to DNA methylation, deregulation in histone modifications has been linked to gastric carcinogenesis and tumor progression. High H3K9me3 levels have been associated with $\mathrm{T}$ stage and gastric cancer recurrence, and it was also able to predict a worse prognosis of a cohort of $261 \mathrm{GC}$ patients [108]. Aberrant histone methylation has been linked to upregulation of genes involved in cell-basement membrane and cell-cell adhesions, such as $L A M B 3$ and $L A M C 2$, and CLDN4 [109]. The H3K4 demethylase KDM5B has been found upregulated in GC tissues (45 paired GC tissues and adjacent non-cancerous tissues), and its ability to promote tumor growth and metastasis 
was demonstrated in vitro [110]. Two Jumonji C-domain demethylases, KDM3A and KDM4A, were significantly associated with TNM stage and revealed to be independent prognostic factors for OS of two different cohorts of 90 and 120 gastric cancer patients [111,112]. One of the most studied HMTs is EZH2, a Polycomb complex protein that methylates H3K27. This enzyme has been shown to interact with DNMTs and shape a carcinogenic methylation profile, and it was found upregulated in many malignancies including GC, predicting worse prognosis of patients and modulating the expression of E-cadherin in vitro $[107,113,114]$.

In the last few years, several data reported the role of EHMT2 (G9a), the HMT targeting H3K9 and H3K27, in promoting carcinogenesis of several malignancies and in predicting depth of infiltration, lymphatic invasion, TNM staging, and prognosis of patients, including patients with GC [115-117]. Inhibition of G9a in GC cell lines suppressed cell growth via cell cycle arrest and autophagy. Interestingly, the authors of that study found a direct control of G9a on mTOR expression, linked to mono- but not di-methylation of H3K9, which was decreased after G9a inhibition [118]. Moreover, G9a can interact with other epigenetic molecules and be recruited to form transcriptional regulatory complexes, e.g., DNMT1/UHRF1/G9a, that coordinates maintenance DNA methylation during replication of somatic cells, or DNMT1/UHRF1/HDAC1/HDAC2/G9a, whose role is still debated $[119,120]$. Recently, it was demonstrated that upregulated G9a forms a functional complex with p300 and glucocorticoid receptor that induces the expression of ITGB3. Interestingly, G9a catalytic activity is not needed for this effect, but this complex promotes cell invasion and migration in GC cell lines, suggesting that it could be a tumor biomarker for targeted therapy [121].

\subsubsection{Histone Acetylation}

Acetylation at lysine residues of histone tails is an epigenetic mechanism that promotes euchromatin conformation and gene expression activation. This reaction is catalyzed by a family of histone acetyltransferases (HATs), and reverted by the so-called histone deacetylases (HDACs) [101]. On the one hand, HATs are a large family of enzymes divided into three main subfamilies, each one targeting a preferential substrate-the GNAT family mainly targets H3, the MYST family mainly targets H4, whereas p300/CREB-binding protein targets both histones. Interestingly, it has been reported that acetylation can also occur on non-histone substrates, a mechanism often affecting cancer-related pathways $[122,123]$. On the other hand, HDACs are divided into the following four classes: class I (HDAC 1, 2, 3, 8, with mainly nuclear localization), class IIa and IIb (HDACs 4, 5, 7, and 9, and 6 and 10 , respectively, with no preferential localization nucleus/cytoplasm), class III (including the sirtuins), and class IV (HDAC 11) [124]. Deregulation in HDAC expression has been linked to carcinogenesis, as HDAC aberrant expression has been found in several malignancies in association with the silencing of tumor suppressor genes [125]. In GC, global hypo-acetylation has been linked to HDACs' class I aberrant expression [126], and reduced levels of acetylated $\mathrm{H} 4$ have been found in $72 \%$ of 18 GC patients, significantly correlated with $\mathrm{T}$ stage, tumor depth invasion, and lymph node metastasis [127]. Elevated levels of HDAC1 have been found in GC specimens compared to adjacent tissue, with a correlation with TNM stage [128]. In another study, HDAC2 levels were associated with neoadjuvant chemoresistance and higher tumor grade [129]. In both studies, HDAC1 levels were associated with worse OS of patients [128,129]. Noguchi et al. were able to correlate high levels of sirtuin1 (class III HDAC) with advanced tumor progression and worse prognosis in a large case series of patients, and they also found decreased levels of p53 expression and histone acetylation at H4K16 and H3K9 [130]. Another evidence that HDACs could prevent apoptosis in GC is provided by the capability of HDAC3 to directly downregulate PUMA (p53-upregulated mediator of apoptosis) gene expression in GC cell lines, with the inhibition of HDAC 3 thus restoring PUMA expression. Moreover, the authors found elevated levels of HDAC3 in GC specimens, predicting a significant decrease in OS of patients [131]. Similar results were achieved by Feng and colleagues who found that downregulation of PUMA in GC specimens was correlated with decreased OS of patients, and that HDAC 3 inhibition alone was able to restore PUMA expression and trigger p53-mediated apoptosis [132]. 


\section{Current and New Epigenetic Strategies for Gastric Cancer Treatment}

As epigenetic aberrations are a relevant hallmark in GC onset and development, several approaches for epigenetic treatment have been proposed (Table 2). As occurs for other solid malignancies, and in spite of numerous preclinical investigations, these therapies have not reached clinical practice yet, albeit there are some interesting emerging indicators of evidence. 
Table 2. Examples of preclinical and clinical evidences of epigenetic strategies for gastric cancer treatment.

\begin{tabular}{|c|c|c|c|c|c|}
\hline $\begin{array}{c}\text { Treatment } \\
\text { Strategy }\end{array}$ & $\begin{array}{c}\text { Epigenetic } \\
\text { Target }\end{array}$ & Drug & Result & Model or Clinical Study Phase & Ref. \\
\hline \multirow{7}{*}{ Single-agent } & DNMTs & 5-azacitidine & Decreased GC incidence and decreased global hypermethylation in vivo & Mongolian gerbils & [133] \\
\hline & DNMTs & 5-azacitidine & Restoration of Gdf2-SMAD2/3 axis & MNU-treated mice & [134] \\
\hline & DNMTs & DAC & Reduction of invasiveness of GC cells & GC cell lines & [135] \\
\hline & DNMTs & DAC & Reduced cell growth in CIMP-positive cell lines & GC cell lines & [136] \\
\hline & HDACs & TSA & Re-establishment of tumor suppressor gene expression & GC cell lines & [137] \\
\hline & HDACs & VA & Inhibition of cell growth and apoptosis trigger & In vitro and in vivo models & [138] \\
\hline & HDAC6 & TC24 & Cell cycle arrest and apoptosis, loss of mitochondrial membrane potential & GC cell lines & [139] \\
\hline \multirow{5}{*}{$\begin{array}{l}\text { Combination } \\
\text { therapy, } \\
\text { epigenetic } \\
\text { priming }\end{array}$} & HDACs & VPA, TSA, SAHA, chemotherapy & Increase of DNA binding of cytotoxic agents and higher cytotoxic potential & GC cell lines & [126] \\
\hline & HMT G9a & G9a siRNA + 5-FU & Apoptosis trigger, synergism with 5-FU & GC cell lines & [140] \\
\hline & HDAC9 & HDAC9 siRNA + cisplatin & Cell cycle arrest and apoptosis, synergism with cisplatin & In vitro and in vivo models & [141] \\
\hline & DNMTs & $\begin{array}{l}\text { 5-azacitidine prior to neoadjuvant } \\
\text { chemotherapy }\end{array}$ & $67 \%$ overall response rate, $25 \%$ complete response & Phase I (NCT01386346) & [142] \\
\hline & HDACs & SAHA + capecitabine, cisplatin & $42 \%$ objective response rate, increased adverse events & Phase II (NCT01045538) & [143] \\
\hline
\end{tabular}

Abbreviations: 5-FU: 5-fluorouracil; DAC: decitabine; DMNT: DNA methyltransferase; GC: gastric cancer; HDAC: histone deacetylase; HMT: histone methyltransferase; MNU:

$N$-nitroso- $N$-methylurea; SAHA: suberoylanilide hydroxamic acid; TSA: trichostatin A; VA: valproic acid. 
To date, two classes of epigenetic drugs achieved the best results in experimental GC treatment, namely DNMT inhibitors (DNMTi) and HDAC inhibitors (HDACi). DNMTi are distinguished into nucleoside (e.g., 5-azacitidine and 5-aza-dC or decitabine (DAC)) and non-nucleoside (hydralazine) analogues, depending on their ability to integrate in the newly synthesized DNA [144]. Compounds from the former group are the only FDA-approved epigenetic monotherapies for the treatment of hematological malignancies. However, their efficacy in solid tumors remains low. This poor performance may be related to their high metabolic clearance in vivo and their instability within the acidic tumor microenvironment of solid tumors [145]. Nevertheless, more promising results in clinical trials have been achieved through combination therapies [145]. The therapeutic effect of 5-aza-dC was tested in $\mathrm{H}$. pylori-positive gerbils, with a consistent diminution of GC incidence and a decreased overall CGI methylation. Interestingly, treatment with 5-aza-dC induced diminished levels of IL-1 $\beta$ and NOS2 and upregulation of TNF, a CGI-lacking gene not affected by methylation [133], suggesting that this treatment is able to reprogram the H. pylori-dependent oncogenic chronic inflammation. The same cancer-preventing effect was demonstrated in mice treated with carcinogen $N$-nitroso- $N$-methylurea (MNU), together with a restoration of the proto-oncogenic axis Gdf1-SMAD2/3, frequently found activated in GC [134].

DAC was able to inhibit matrix metalloproteinases 2 and 9 (MMP-2 and MMP-9) activity through the upregulation of their inhibitors TIMP-1 and TIMP-2 in vitro, reducing invasiveness of cells. More importantly, DAC treatment reduced the levels of pAKT, implicated in tight junction dynamics and MMP activation [135]. Another study tested the effect of DAC on 17 GC cell lines, finding an increased reduction in cell growth in the 17 CIMP cell lines [136].

The great potential of DNMTi in GC stands in overcoming resistance in chemotherapy and radiotherapy treatments. In fact, aberrant methylation patterns, especially in tumor suppressor genes involved in programmed cell death processes, have been linked to chemoresistance to 5-FU, platinum-based and irinotecan treatments, and resistance to radiation therapies [81]. In this setting, priming with 5-azacitidine prior to standard chemotherapy has been investigated in a clinical trial. Patients with resectable gastro-esophageal cancers were treated with the epigenetic agent prior to neoadjuvant epirubicin-oxaliplatin-capecitabine, achieving an overall response rate of $67 \%$, and $25 \%$ benefited of complete response. Interestingly, the authors demonstrated hypomethylation of tumor-associated loci for all doses of 5-azacitidine, and that hypomethylation levels tended to be associated with the therapeutic response [142]. In another study conducted on five GC cell lines, epigenetic treatments were also able to increase radiosensitivity in three of them, re-establishing the expression of tumor suppressor genes involved in apoptosis [146]. In this direction, further studies are needed to better understand the interaction of epigenetic treatments and radiation therapy, given that these interesting results seem to be cell-type associated. Thus, despite the described side effects of epigenetic agents [140], the combination of these with chemo- and radiotherapy is a promising strategy and a hot topic for GC treatment, to maximize the potential of cytotoxic agents and radiation therapy. In recent years, non-nucleoside epigenetic compounds are attracting growing interest, because of their lower toxicity and the ability to bind and inhibit the catalytic domain of DNMTs, without integrating in DNA, and thus avoiding the non-specific effects of nucleoside analogues [102].

In GC, most of the preclinical evidences of epigenetic treatment have been provided through HDAC inhibition. HDACi compounds are biochemically divided into the following four classes: short-chain fatty acids, hydroxamates, cyclic tetrapeptides, and benzamides [124].

Like DNMT inhibition, HDACi are able to synergize with chemotherapeutic agents $[129,141,147]$ and radiation therapy [6]. For this reason, the ability of HDACi to act as priming drugs for chemotherapy agents was investigated. A recent study showed that treatment of the GC cell line AGS with different HDACi prior to chemotherapy agents resulted in a better binding of chemotherapies to chromatin, with lower doses needed to achieve maximum efficacy when the drugs were administered in combination [126]. However, data from a phase II clinical trial combining HDACi (Vorinostat) with capecitabine-cisplatin in advanced GC patients showed an objective response rate of $42 \%$, not 
appearing to improve the clinical outcome of patients, and with a considerable rate of grade 3-4 adverse events [143].

Another preclinical study proved that HDACi treatment re-established the expression of tumor suppressor genes PER1 and PER2, mainly known as circadian regulators, that are involved in cell cycle arrest, apoptosis, and loss of clonogenic activity [137]. Valproic acid, largely used as a anticonvulsant drug, has been recently studied for its HDACi ability, and it was demonstrated to target HDAC1/2 and the HDAC1/PTEN/Akt axis in GC cell lines, inhibiting cell growth and triggering apoptosis [138].

A role for HDAC 9 as a targetable biomarker has been recently proposed by Xiong et al., highlighting its aberrant expression and a correlation with patients' survival. Interestingly, the authors found that pharmacological targeting of HDAC9 inhibits cell survival and induces cell cycle arrest with consequent apoptosis, synergizing with the effects of cisplatin [141]. Similarly, Dong et al. uncovered the anticancer effects of a specific HDAC6i, able to induce cell cycle arrest and apoptosis. Moreover, the authors observed a decrease in neo-angiogenetic biomarkers and a loss in mitochondrial membrane potential [139]. Since not all epigenetic targets are equally expressed in GC, these are nice examples that targeting a specific epigenetic effector could be a good strategy for better tailoring precision medicine and possibly diminishing the side effects observed with pan-HDACi [143]. In fact, the therapeutic mechanism of action of HDACi is not fully understood, and HDACs have a wide range of targets, not only increasing histone acetylation, but also through a plethora of antitumoral mechanisms, including direct cytotoxic effects [6]. Interestingly, in a preclinical model of hepatocellular carcinoma, treatment with an HDAC pan-inhibitor resulted in the downregulation of DNMT expression and activity [148].

Considering the side effects of a pan-inhibition, and that epigenetic mechanisms often cooperate with each other to shape an aberrant profile, a targeted dual inhibition of epigenetic mechanisms could be an attractive strategy to test in GC models. A dual targeting of two HMTs, EZH2 and G9a, was performed in preclinical models of breast cancer. The authors of that study demonstrated a global restoration of gene expression, and inhibition of cell growth. Moreover, they found that the dual inhibition achieved the re-expression of a subset of genes that would not be re-expressed with a single agent [149]. Nevertheless, further studies are needed to assess the toxicity profile of such treatment. In GC cells, depletion of HMT G9a effectively reduced levels of histone methylation and triggered apoptosis [117], and, as in the case of other epigenetic treatments, increased the chemosensitivity of cells to 5-FU [150]. Moreover, G9a can be recruited by other epigenetic inhibitors to exert autophagy-mediated apoptosis [151], and can form transcriptional regulator complexes with DNMTs, maintaining an active crosstalk with these molecules $[120,152]$. Moreover, Wozniak et al. demonstrated, in breast cancer cells, that G9a is regulated by 5 -aza-dC through a dose-dependent post-transcriptional mechanism, and the addition of siRNA blocking both G9a and DNMT1 resulted in increased expression of tumor suppressor genes, suggesting that multiple layers of epigenetic deregulation cooperate in a single cellular context [153]. Dual inhibition of G9a and DNMT1 has been successfully attempted in preclinical models of hepatocellular carcinoma. The effective antitumoral activity in vitro and in vivo of the tested compound was demonstrated, with a synergistic effect with chemotherapy and other epigenetic drugs. Interestingly, dual targeting of G9a and DNMT1 reprogrammed the metabolic adaptation to hypoxia of cancer cells, with a diminished glucose intake and a general diminished expression of glycolytic enzymes [154]. Similar to other malignancies, GC is addicted to glucose consumption, aerobic glycolysis, and the establishment of an acidic microenvironment through accumulation of lactic acid, resulting in a growth advantage for cancer cells via adaptation to hypoxia [155]. In this scenario, it could be useful to clarify how epigenetic targeting could remodel metabolic activity of cancer cells, forcing them to a less advantaged condition and a less aggressive metabolic behavior.

In the era of immuno-oncology, GC has revealed to be a tumor with weak immunogenicity, and despite encouraging results, the response rates in clinical trials with immune checkpoint inhibitors remain limited [32,156]. In this setting, emerging data on immunotherapy for GC highlight that expression of immune biomarkers is epigenetically regulated, and that epigenetic mechanisms are able to predict clinical response to immune checkpoint inhibitors [157-160]. Moreover, the aberrant 
epigenome of GC was revealed to contribute to cancer immunoediting and to immune escape of cancer cells [161]. Conversely, activated immune cells were able to induce the downregulation of tumor suppressor genes through DNMT1 recruitment and activation [162]. Aberrant epigenome of cancer cells and an exhausted T-cell tumor infiltrate are features deeply characterizing GC, and represent a possible walkable way for new treatment strategies. Moreover, in CIMP gastrointestinal malignancies and other non-gastric tumors, epigenetic strategies targeting the cancer epigenome could increase cancer immunogenicity likely to respond to immunotherapeutic agents by reprogramming the tumor immune microenvironment. Moreover, a recent study in GC demonstrated that unresponsiveness to anti-PD-1 antibodies could be the result of epigenetic silencing of PD-L1 [163-166]. Hence, in the near future, an attractive approach could be a strategy to test the combination of epigenetic and immunotherapeutic agents in GC models.

\section{Conclusions}

GC is one of the major causes of cancer-related deaths worldwide. Epigenetic mechanisms stand at the base of carcinogenesis and progression of the disease and, together with risk factors and genetic alterations, they are able to guide gastric malignancy development. However, altered epigenomic profiles could represent the cancer susceptibility for novel therapeutic strategies for gastric cancer (Figure 1). In fact, targeting epigenetic mechanisms could overcome cancer heterogeneity and reprogram the cancer homeostasis likely to respond to cytotoxic agents or immune checkpoint inhibitors. In this way, it could be possible to combine several epigenetic strategies, or use them with standard chemotherapies or immunotherapies.

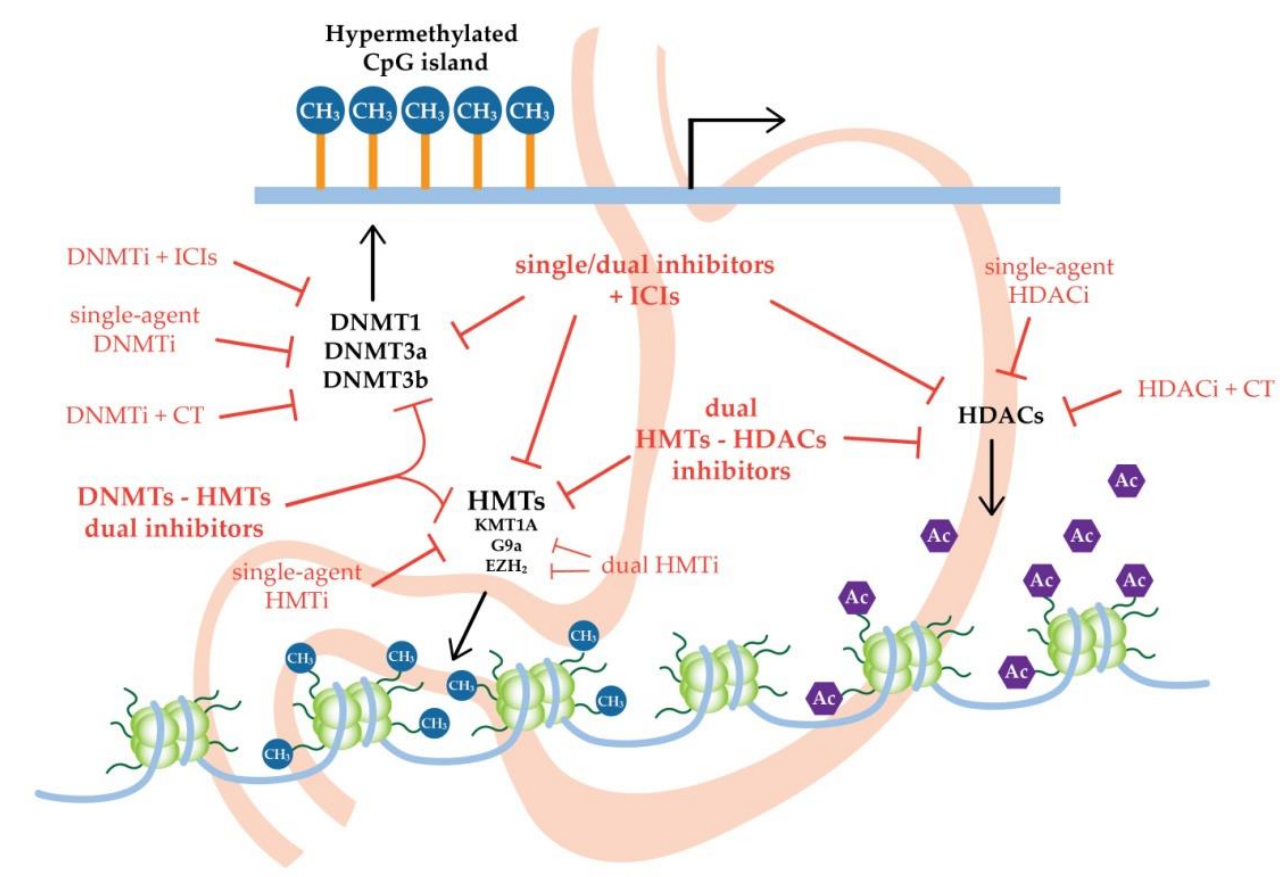

Figure 1. Promising new epigenetic strategies for gastric cancer treatment. CT: chemotherapy; DNMTs: DNA methyltransferases; DNMTi: DNA methyltransferase inhibitor; HDACs: histone deacetylases; HDACi: histone deacetylase inhibitor; HMTs: histone methyltransferases; HMTi: histone methyltransferase inhibitor; ICIs: immune-checkpoint inhibitors.

Funding: La Caixa Foundation HEPACARE Project to M.A., C.B., M.G.F.B. and M.A.A.; Ramón y Cajal Program contract RYC2018-024475-1 to M.G.F.B.

Acknowledgments: M.A. was supported by a post-doctoral fellowship from Asociación Española Contra el Cáncer (AECC), Madrid, Spain. 
Conflicts of Interest: The authors declare no conflict of interest.

\section{References}

1. Bray, F.; Ferlay, J.; Soerjomataram, I.; Siegel, R.L.; Torre, L.A.; Jemal, A. Global cancer statistics 2018: GLOBOCAN estimates of incidence and mortality worldwide for 36 cancers in 185 countries. CA Cancer J. Clin. 2018, 68, 394-424. [CrossRef]

2. American Cancer Society. Cancer Facts E Figures 2020; American Cancer Society: Atlanta, GA, USA, 2020.

3. IARC Working Group on the Evaluation of Carcinogenic Risks to Humans. Personal habits and indoor combustions. Volume 100 E. A review of human carcinogens. IARC Monogr. Eval. Carcinog. Risks Hum. 2012, $100,1-538$.

4. Plummer, M.; Franceschi, S.; Vignat, J.; Forman, D.; de Martel, C. Global burden of gastric cancer attributable to Helicobacter pylori. Int. J. Cancer 2015, 136, 487-490. [CrossRef] [PubMed]

5. Ebrahimi, V.; Soleimanian, A.; Ebrahimi, T.; Azargun, R.; Yazdani, P.; Eyvazi, S.; Tarhriz, V. Epigenetic modifications in gastric cancer: Focus on DNA methylation. Gene 2020, 742, 144577. [CrossRef] [PubMed]

6. Abdelfatah, E.; Kerner, Z.; Nanda, N.; Ahuja, N. Epigenetic therapy in gastrointestinal cancer: The right combination. Ther. Adv. Gastroenterol. 2016, 9, 560-579. [CrossRef] [PubMed]

7. Bornschein, J.; Malfertheiner, P. Gastric carcinogenesis. Langenbeck's Arch. Surg. 2011, 396, 729-742. [CrossRef] [PubMed]

8. Correa, P. Human gastric carcinogenesis: A multistep and multifactorial process-First American Cancer Society Award Lecture on Cancer Epidemiology and Prevention. Cancer Res. 1992, 52, 6735-6740. [PubMed]

9. Hayakawa, Y.; Fox, J.G.; Wang, T.C. The Origins of Gastric Cancer From Gastric Stem Cells. Cell Mol. Gastroenterol. Hepatol. 2017, 3, 331-338. [CrossRef] [PubMed]

10. Graham, T.A.; McDonald, S.A.; Wright, N.A. Field cancerization in the GI tract. Future Oncol. 2011, 7, $981-993$. [CrossRef]

11. Baba, Y.; Ishimoto, T.; Kurashige, J.; Iwatsuki, M.; Sakamoto, Y.; Yoshida, N.; Watanabe, M.; Baba, H. Epigenetic field cancerization in gastrointestinal cancers. Cancer Lett. 2016, 375, 360-366. [CrossRef]

12. Sitaraman, R. Helicobacter pylori DNA methyltransferases and the epigenetic field effect in cancerization. Front. Microbiol. 2014, 5, 115. [CrossRef] [PubMed]

13. Van Cutsem, E.; Sagaert, X.; Topal, B.; Haustermans, K.; Prenen, H. Gastric cancer. Lancet 2016, 388, $2654-2664$. [CrossRef]

14. Siewert, J.R.; Stein, H.J. Classification of adenocarcinoma of the oesophagogastric junction. Br. J. Surg. 1998, 85, 1457-1459. [PubMed]

15. American Joint Committee on Cancer. JCC Cancer Staging Manual; Springer: New York, NY, USA, 2017.

16. Lauren, P. The two histological main types of gastric carcinoma: Diffuse and so-called intestinal-type carcinoma. An attempt at a histo-clinical classification. Acta Pathol. Microbiol. Scand. 1965, 64, 31-49. [CrossRef]

17. Lauwers, G.; Carneiro, F.; Graham, D.Y. WHO classification of tumours of the digestive system-3rd chapter. In WHO Classifcation Tumours Dig Syst, 4th ed.; IARC: Lyon, France, 2010; pp. 44-58.

18. Cancer Genome Atlas Research Network. Comprehensive molecular characterization of gastric adenocarcinoma. Nature 2014, 513, 202-209. [CrossRef] [PubMed]

19. Cristescu, R.; Lee, J.; Nebozhyn, M.; Kim, K.-M.; Ting, J.C.; Wong, S.S.; Liu, J.; Yue, Y.G.; Wang, J.; Yu, K.; et al. Molecular analysis of gastric cancer identifies subtypes associated with distinct clinical outcomes. Nat. Med. 2015, 21, 449-456. [CrossRef]

20. Lutz, M.; Zalcberg, J.R.; Ducreux, M.; Ajani, J.A.; Allum, W.; Aust, D.; Bang, Y.-J.; Cascinu, S.; Hölscher, A.; Jankowski, J.; et al. Highlights of the EORTC St. Gallen International Expert Consensus on the primary therapy of gastric, gastroesophageal and oesophageal cancer-differential treatment strategies for subtypes of early gastroesophageal cancer. Eur. J. Cancer 2012, 48, 2941-2953. [CrossRef]

21. Van Cutsem, E.; Dicato, M.; Geva, R.; Arber, N.; Bang, Y.; Benson, A.; Cervantes, A.; Diaz-Rubio, E.; Ducreux, M.; Glynne-Jones, R.; et al. The diagnosis and management of gastric cancer: Expert discussion and recommendations from the 12th ESMO/World Congress on Gastrointestinal Cancer, Barcelona, 2010. Ann. Oncol. Off. J. Eur. Soc. Med. Oncol. 2011, 22 (Suppl. 5), v1-v9. [CrossRef] 
22. Schmidt, B.; Yoon, S.S. D1 versus D2 lymphadenectomy for gastric cancer. J. Surg. Oncol. 2013, 107, $259-264$. [CrossRef]

23. Wagner, A.D.; Unverzagt, S.; Grothe, W.; Kleber, G.; Grothey, A.; Haerting, J.; Fleig, W.E. Chemotherapy for advanced gastric cancer. Cochrane Database Syst. Rev. 2010, CD004064. [CrossRef]

24. Glimelius, B.; Ekström, K.; Hoffman, K.; Graf, W.; Sjödén, P.-O.; Haglund, U.; Svensson, C.; Enander, L.-K.; Linné, T.; Sellsröm, H.; et al. Randomized comparison between chemotherapy plus best supportive care with best supportive care in advanced gastric cancer. Ann. Oncol. Off. J. Eur. Soc. Med. Oncol. 1997, 8, 163-168. [CrossRef] [PubMed]

25. Van Cutsem, E.; Moiseyenko, V.M.; Tjulandin, S.; Majlis, A.; Constenla, M.; Boni, C.; Rodrigues, A.; Fodor, M.; Chao, Y.; Voznyi, E.; et al. Phase III study of docetaxel and cisplatin plus fluorouracil compared with cisplatin and fluorouracil as first-line therapy for advanced gastric cancer: A report of the V325 Study Group. J. Clin. Oncol. Off. J. Am. Soc. Clin. Oncol. 2006, 24, 4991-4997. [CrossRef] [PubMed]

26. Bang, Y.-J.; Van Cutsem, E.; Feyereislova, A.; Chung, H.C.; Shen, L.; Sawaki, A.; Lordick, F.; Ohtsu, A.; Omuro, Y.; Satoh, T.; et al. Trastuzumab in combination with chemotherapy versus chemotherapy alone for treatment of HER2-positive advanced gastric or gastro-oesophageal junction cancer (ToGA): A phase 3, open-label, randomised controlled trial. Lancet 2010, 376, 687-697. [CrossRef]

27. Shitara, K.; Bang, Y.-J.; Iwasa, S.; Sugimoto, N.; Ryu, M.-H.; Sakai, D.; Chung, H.-C.; Kawakami, H.; Yabusaki, H.; Lee, J.; et al. Trastuzumab Deruxtecan in Previously Treated HER2-Positive Gastric Cancer. N. Engl. J. Med. 2020, 382, 2419-2430. [CrossRef] [PubMed]

28. Fuchs, C.S.; Tomasek, J.; Yong, C.J.; Dumitru, F.; Passalacqua, R.; Goswami, C.; Safran, H.; Santos, L.; Aprile, G.; Ferry, D.R.; et al. Ramucirumab monotherapy for previously treated advanced gastric or gastro-oesophageal junction adenocarcinoma (REGARD): An international, randomised, multicentre, placebo-controlled, phase 3 trial. Lancet 2014, 383, 31-39. [CrossRef]

29. Wilke, H.; Muro, K.; Van Cutsem, E.; Oh, S.-C.; Bodoky, G.; Shimada, Y.; Hironaka, S.; Sugimoto, N.; Lipatov, O.; Kim, T.-Y.; et al. Ramucirumab plus paclitaxel versus placebo plus paclitaxel in patients with previously treated advanced gastric or gastro-oesophageal junction adenocarcinoma (RAINBOW): A double-blind, randomised phase 3 trial. Lancet Oncol. 2014, 15, 1224-1235. [CrossRef]

30. Lazar, D.C.; Taban, S.; Cornianu, M.; Faur, A.; Goldis, A. New advances in targeted gastric cancer treatment. World J. Gastroenterol. 2016, 22, 6776-6799. [CrossRef]

31. Song, H.; Zhu, J.; Lu, D.; Song, H.; Zhu, J.; Lu, D. Molecular-targeted first-line therapy for advanced gastric cancer. Cochrane Database Syst. Rev. 2016, 7, CD011461. [CrossRef]

32. Yang, L.; Wang, Y.; Wang, H. Use of immunotherapy in the treatment of gastric cancer (Review). Oncol. Lett. 2019, 18, 5681-5690. [CrossRef]

33. Coutzac, C.; Pernot, S.; Chaput, N.; Zaanan, A. Critical Reviews in Oncology/Hematology Immunotherapy in advanced gastric cancer, is it the future ? Crit. Rev. Oncol./Hematol. 2019, 133, 25-32. [CrossRef]

34. Li, Y.; Liang, J.; Hou, P. Hypermethylation in gastric cancer. Clin. Chim. Act. 2015, 448, 124-132. [CrossRef] [PubMed]

35. Yoda, Y.; Takeshima, H.; Niwa, T.; Kim, J.G.; Ando, T.; Kushima, R.; Sugiyama, T.; Katai, H.; Noshiro, H.; Ushijima, T. Integrated analysis of cancer-related pathways affected by genetic and epigenetic alterations in gastric cancer. Gastric Cancer 2015, 18, 65-76. [CrossRef] [PubMed]

36. Peng, Y.; Wu, Q.; Wang, L.; Wang, H.; Yin, F. A DNA methylation signature to improve survival prediction of gastric cancer. Clin. Epigenet. 2020, 12, 15. [CrossRef] [PubMed]

37. Li, C.; Zheng, Y.; Pu, K.; Zhao, D.; Wang, Y.; Guan, Q.; Zhou, Y. A four-DNA methylation signature as a novel prognostic biomarker for survival of patients with gastric cancer. Cancer Cell Int. 2020, 20, 1-10. [CrossRef] [PubMed]

38. Bai, Y.; Wei, C.; Zhong, Y.; Zhang, Y.; Long, J.; Huang, S.; Xie, F.; Tian, Y.; Wang, X.; Zhao, H.; et al. Development and validation of a prognostic nomogram for gastric cancer based on DNA methylation-driven differentially expressed genes. Int. J. Biol. Sci. 2020, 16, 1153-1165. [CrossRef] [PubMed]

39. Dragomir, M.P.; Kopetz, S.; Ajani, J.A.; Calin, G.A. Non-coding RNAs in GI cancers: From cancer hallmarks to clinical utility. Gut 2020, 69, 748-763. [CrossRef] [PubMed]

40. Wu, X.; Zhang, Y. TET-mediated active DNA demethylation: Mechanism, function and beyond. Nat. Rev. Genet. 2017, 18, 517-534. [CrossRef] 
41. Padmanabhan, N.; Ushijima, T.; Tan, P. How to stomach an epigenetic insult: The gastric cancer epigenome. Nat. Rev. Gastroenterol. Hepatol. 2017, 14, 467-478. [CrossRef]

42. Matsusaka, K.; Kaneda, A.; Nagae, G.; Ushiku, T.; Kikuchi, Y.; Hino, R.; Uozaki, H.; Seto, Y.; Takada, K.; Aburatani, H.; et al. Classification of Epstein-Barr virus-positive gastric cancers by definition of DNA methylation epigenotypes. Cancer Res. 2011, 71, 7187-7197. [CrossRef]

43. Corso, G.; Carvalho, J.; Marrelli, D.; Vindigni, C.; Carvalho, B.; Seruca, R.; Roviello, F.; Oliveira, C. Somatic mutations and deletions of the e-cadherin gene predict poor survival of patients with gastric cancer. J. Clin. Oncol. 2013, 31, 868-875. [CrossRef]

44. van der Post, R.S.; Vogelaar, I.P.; Carneiro, F.; Guilford, P.; Huntsman, D.; Hoogerbrugge, N.; Caldas, C.; Schreiber, K.E.C.; Hardwick, R.H.; Ausems, M.G.E.M.; et al. Hereditary diffuse gastric cancer: Updated clinical guidelines with an emphasis on germline CDH1 mutation carriers. J. Med. Genet. 2015, 52, 361-374. [CrossRef] [PubMed]

45. Machado, J.C.; Oliveira, C.; Carvalho, R.; Soares, P.; Berx, G.; Caldas, C.; Seruca, R.; Carneiro, F.; Sobrinho-Simöes, M. E-cadherin gene (CDH1) promoter methylation as the second hit in sporadic diffuse gastric carcinoma. Oncogene 2001, 20, 1525-1528. [CrossRef] [PubMed]

46. Carneiro, P.; Fernandes, M.S.; Figueiredo, J.; Caldeira, J.; Carvalho, J.; Pinheiro, H.; Leite, M.; Melo, S.; Oliveira, P.; Simões-Correia, J.; et al. E-cadherin dysfunction in gastric cancer-Cellular consequences, clinical applications and open questions. FEBS Lett. 2012, 586, 2981-2989. [CrossRef]

47. Tahara, T.; Shibata, T.; Arisawa, T.; Nakamura, M.; Yamashita, H.; Yoshioka, D.; Okubo, M.; Yonemura, J.; Maeda, Y.; Maruyama, N.; et al. CpG island promoter methylation (CIHM) status of tumor suppressor genes correlates with morphological appearances of gastric cancer. Anticancer Res. 2010, 30, 239-244. [PubMed]

48. Balassiano, K.; Lima, S.; Jenab, M.; Overvad, K.; Tjonneland, A.; Boutron-Ruault, M.C.; Clavel-Chapelon, F.; Canzian, F.; Kaaks, R.; Boeing, H.; et al. Aberrant DNA methylation of cancer-associated genes in gastric cancer in the European Prospective Investigation into Cancer and Nutrition (EPIC-EURGAST). Cancer Lett. 2011, 311, 85-95. [CrossRef]

49. Shenoy, S. CDH1 (E-cadherin) mutation and gastric cancer: Genetics, molecular mechanisms and guidelines for management. Cancer Manag. Res. 2019, 11, 10477-10486. [CrossRef]

50. Liu, X.; Chu, K.M. E-cadherin and gastric cancer: Cause, consequence, and applications. Biomed. Res. Int. 2014, 2014, 1-9. [CrossRef]

51. Chan, A.O.O.; Wong, B.C.Y.; Lan, H.Y.; Loke, S.L.; Chan, W.K.; Hui, W.M.; Yuen, Y.H.; Ng, I.; Hou, L.; Wong, W.M.; et al. Deregulation of E-cadherin-catenin complex in precancerous lesions of gastric adenocarcinoma. J. Gastroenterol. Hepatol. 2003, 18, 534-539. [CrossRef]

52. Chan, A.O.O.; Peng, J.Z.; Lam, S.K.; Lai, K.C.; Yuen, M.F.; Cheung, H.K.L.; Kwong, Y.L.; Rashid, A.; Chan, C.K.; Wong, B.C.-Y. Eradication of Helicobacter pylori infection reverses E-cadherin promoter hypermethylation. Gut 2006, 55, 463-468. [CrossRef]

53. Zeng, W.; Zhu, J.; Shan, L.; Han, Z.; Aerxiding, P.; Quhai, A.; Zeng, F.; Wang, Z.; Li, H. The clinicopathological significance of CDH1 in gastric cancer: A meta-analysis and systematic review. Drug Des. Devel. Ther. 2015, 9, 2149-2157. [CrossRef]

54. Graziano, F.; Arduini, F.; Ruzzo, A.; Mandolesi, A.; Bearzi, I.; Silva, R.; Muretto, P.; Testa, E.; Mari, D.; Magnani, M.; et al. Combined analysis of E-cadherin gene (CDH1) promoter hypermethylation and E-cadherin protein expression in patients with gastric cancer: Implications for treatment with demethylating drugs. Ann Oncol. 2004, 15, 489-492. [CrossRef]

55. Li, G.M. Mechanisms and functions of DNA mismatch repair. Cell Res. 2008, 18, 85-98. [CrossRef]

56. Harfe, B.D.; Jinks-Robertson, S. Mismatch repair proteins and mitotic genome stability. Mutat. Res.-Fundam. Mol. Mech. Mutagen. 2000, 451, 151-167. [CrossRef]

57. Baretti, M.; Le, D.T. DNA mismatch repair in cancer. Pharmacol. Ther. 2018, 189, 45-62. [CrossRef]

58. Li, Y.; Yang, Y.; Lu, Y.; Herman, J.G.; Brock, M.V.; Zhao, P.; Guo, M. Predictive value of CHFR and MLH1 methylation in human gastric cancer. Gastric Cancer 2015, 18, 280-287. [CrossRef]

59. Kitajima, Y.; Miyazaki, K.; Matsukura, S.; Tanaka, M.; Sekiguchi, M. Loss of expression of DNA repair enzymes MGMT, hMLH1, and hMSH2 during tumor progression in gastric cancer. Gastric Cancer 2003, 6, 86-95. [CrossRef] [PubMed] 
60. Shigeyasu, K.; Nagasaka, T.; Mori, Y.; Yokomichi, N.; Kawai, T.; Fuji, T.; Kimura, K.; Umeda, Y.; Kagawa, S.; Goel, A.; et al. Clinical significance of MLH1 methylation and CpG island methylator phenotype as prognostic markers in patients with gastric cancer. PLoS ONE 2015, 10, e0130409. [CrossRef] [PubMed]

61. Balgkouranidou, I.; Matthaios, D.; Karayiannakis, A.; Bolanaki, H.; Michailidis, P.; Xenidis, N.; Amarantidis, K.; Chelis, L.; Trypsianis, G.; Chatzaki, E.; et al. Prognostic role of APC and RASSF1A promoter methylation status in cell free circulating DNA of operable gastric cancer patients. Mutat. Res. Fundam. Mol. Mech. Mutagen. 2015, 778, 46-51. [CrossRef]

62. Fang, J.Y.; Zhu, S.S.; Xiao, S.D.; Jiang, S.J.; Shi, Y.; Chen, X.Y.; Zhou, X.M.; Qian, L.F. Studies on the hypomethylation of c-myc, c-Ha-ras oncogenes and histopathological changes in human gastric carcinoma. J. Gastroenterol. Hepatol. 1996, 11, 1079-1082. [CrossRef]

63. Yu, J.; Tao, Q.; Cheng, Y.Y.; Lee, K.Y.; Ng, S.S.M.; Cheung, K.F.; Tian, L.; Rha, S.Y.; Neumann, U.; Röcken, C.; et al. Promoter methylation of the $\mathrm{Wnt} / \beta$-catenin signaling antagonist Dkk-3 is associated with poor survival in gastric cancer. Cancer 2009, 115, 49-60. [CrossRef]

64. Ksiaa, F.; Ziadi, S.; Amara, K.; Korbi, S.; Trimeche, M. Biological significance of promoter hypermethylation of tumor-related genes in patients with gastric carcinoma. Clin. Chim. Acta 2009, 404, 128-133. [CrossRef] [PubMed]

65. Zhou, Y.; Wang, X.-B.; Qiu, X.-P.; Zhang, S.; Wang, C.; Zheng, F. CDKN2A promoter methylation and hepatocellular carcinoma risk: A meta-analysis. Clin. Res. Hepatol. Gastroenterol. 2018, 42, 529-541. [CrossRef] [PubMed]

66. Xing, X.; Cai, W.; Shi, H.; Wang, Y.; Li, M.; Jiao, J.; Chen, M. The prognostic value of CDKN2A hypermethylation in colorectal cancer: A meta-analysis. Br. J. Cancer 2013, 108, 2542-2548. [CrossRef]

67. He, D.; Zhang, Y.-W.; Zhang, N.-N.; Zhou, L.; Chen, J.-N.; Jiang, Y.; Shao, C.-K. Aberrant gene promoter methylation of p16, FHIT, CRBP1, WWOX, and DLC-1 in Epstein-Barr virus-associated gastric carcinomas. Med. Oncol. 2015, 32, 1-16. [CrossRef] [PubMed]

68. Dong, C.X.; Deng, D.J.; Pan, K.F.; Zhang, L.; Zhang, Y.; Zhou, J.; You, W.C. Promoter methylation of p16 associated with helicobacter pylori infection in precancerous gastric lesions: A population-based study. Int. J. Cancer 2009, 124, 434-439. [CrossRef]

69. Ryan, J.L.; Jones, R.J.; Kenney, S.C.; Rivenbark, A.G.; Tang, W.; Knight, E.R.; Coleman, W.B.; Gulley, M.L. Epstein-Barr virus-specific methylation of human genes in gastric cancer cells. Infect. Agents Cancer 2010, 5, 27. [CrossRef]

70. Shin, C.M.; Kim, N.; Park, J.H.; Kang, G.H.; Kim, J.S.; Jung, H.C.; Song, I.S. Prediction of the risk for gastric cancer using candidate methylation markers in the non-neoplastic gastric mucosae. J. Pathol. 2012, 226, 654-665. [CrossRef]

71. Abbaszadegan, M.R.; Moaven, O.; Sima, H.R.; Ghafarzadegan, K.; A'rabi, A.; Forghani, M.N.; Raziee, H.R.; Mashhadinejad, A.; Jafarzadeh, M.; Esmaili-Shandiz, E.; et al. p16 promoter hypermethylation: A useful serum marker for early detection of gastric cancer. World J. Gastroenterol. 2008, 14, 2055-2060. [CrossRef]

72. Ichikawa, D.; Koike, H.; Ikoma, H.; Ikoma, D.; Tani, N.; Otsuji, E.; Kitamura, K.; Yamagishi, H. Detection of aberrant methylation as a tumor marker in serum of patients with gastric cancer. Anticancer Res. 2004, 24, 2477-2481. [PubMed]

73. Pimson, C.; Ekalaksananan, T.; Pientong, C.; Promthet, S.; Putthanachote, N.; Suwanrungruang, K.; Wiangnon, S. Aberrant methylation of PCDH10 and RASSF1A genes in blood samples for non-invasive diagnosis and prognostic assessment of gastric cancer. PeerJ 2016, 4, e2112. [CrossRef] [PubMed]

74. Li, Q.; Ito, K.; Sakakura, C.; Fukamachi, H.; Inoue, K.-I.; Chi, X.Z.; Lee, K.Y.; Nomura, S.; Lee, C.W.; Han, S.B.; et al. Causal relationship between the loss of RUNX3 expression and gastric cancer. Cell 2002, 109, 113-124. [CrossRef]

75. Kim, T.Y.; Lee, H.J.; Hwang, K.S.; Lee, M.; Kim, J.W.; Bang, Y.J.; Kang, G.H. Methylation of RUNX3 in various types of human cancers and premalignant stages of gastric carcinoma. Lab. Investig. 2004, 84, 479-484. [CrossRef]

76. Jeltsch, A.; Ehrenhofer-Murray, A.; Jurkowski, T.P.; Lyko, F.; Reuter, G.; Ankri, S.; Nellen, W.; Schaefer, M.; Helm, M. Mechanism and biological role of Dnmt2 in Nucleic Acid Methylation. RNA Biol. 2017, 14, 1108-1123. [CrossRef] [PubMed]

77. Greenberg, M.V.C.; Bourc'his, D. The diverse roles of DNA methylation in mammalian development and disease. Nat. Rev. Mol. Cell Biol. 2019, 20, 590-607. [CrossRef] 
78. Howell, C.Y.; Bestor, T.H.; Ding, F.; Latham, K.E.; Mertineit, C.; Trasler, J.M.; Chaillet, J.R. Genomic imprinting disrupted by a maternal effect mutation in the Dnmt1 gene. Cell 2001, 104, 829-838. [CrossRef]

79. Okano, M.; Bell, D.W.; Haber, D.A.; Li, E. DNA methyltransferases Dnmt3a and Dnmt3b are essential for de novo methylation and mammalian development. Cell 1999, 99, 247-257. [CrossRef]

80. Zhang, W.; Xu, J. DNA methyltransferases and their roles in tumorigenesis. Biomark. Res. 2017, 5, 1-8. [CrossRef]

81. Fattahi, S.; Kosari-Monfared, M.; Ghadami, E.; Golpour, M.; Khodadadi, P.; Ghasemiyan, M.; Niaki, H.-A. Infection-associated epigenetic alterations in gastric cancer: New insight in cancer therapy. J. Cell Physiol. 2018, 233, 9261-9270. [CrossRef]

82. Yang, J.; Wei, X.; Wu, Q.; Xu, Z.; Gu, D.; Jin, Y.; Shen, Y.; Huang, H.; Fan, H.; Chen, J. Clinical significance of the expression of DNA methyltransferase proteins in gastric cancer. Mol. Med. Rep. 2011, 4, 1139-1143.

83. Mutze, K.; Langer, R.; Schumacher, F.; Becker, K.; Ott, K.; Novotny, A.; Hapfelmeier, A.; Höfler, H.; Keller, G. DNA methyltransferase 1 as a predictive biomarker and potential therapeutic target for chemotherapy in gastric cancer. Eur. J. Cancer 2011, 47, 1817-1825. [CrossRef]

84. Ma, T.; Li, H.; Sun, M.; Yuan, Y.; Sun, L.P. DNMT1 overexpression predicting gastric carcinogenesis, subsequent progression and prognosis: A meta and bioinformatic analysis. Oncotarget 2017, 8, 96396-96408. [CrossRef] [PubMed]

85. Jiang, J.; Jia, Z.; Cao, D.; Jin, M.S.; Kong, F.; Suo, J.; Cao, X. Polymorphisms of the DNA Methyltransferase 1 Associated with Reduced Risks of Helicobacter pylori Infection and Increased Risks of Gastric Atrophy. PLOS ONE 2012, 7, e46058. [CrossRef] [PubMed]

86. Jia, Z.; Wu, X.; Cao, D.; Wang, C.; You, L.; Jin, M.; Wen, S.; Cao, X.; Jiang, J. Polymorphisms of the DNA Methyltransferase 1 Gene Predict Survival of Gastric Cancer Patients Receiving Tumorectomy. Dis. Mark. 2016, 1-9. [CrossRef] [PubMed]

87. Hu, J.; Fan, H.; Liu, D.; Zhang, S.; Zhang, F.; Xu, H. DNMT3B promoter polymorphism and risk of gastric cancer. Dig. Dis. Sci. 2010, 55, 1011-1016. [CrossRef] [PubMed]

88. Wang, C.; Jia, Z.; Ma, H.; Cao, D.; Wu, X.; Wen, S.; You, L.; Cao, X.; Jiang, J. DNA methyltransferase 3a rs1550117 genetic polymorphism predicts poor survival in gastric cancer patients. Int. J. Clin. Exp. Pathol. 2015, 8, 14864-14874.

89. Fan, H.; Liu, D.; Qiu, X.; Qiao, F.; Wu, Q.; Su, X.; Zhang, F.; Song, Y.; Zhao, Z. A functional polymorphism in the DNA methyltransferase-3A promoter modifies the susceptibility in gastric cancer but not in esophageal carcinoma. BMC Med. 2010, 8, 12. [CrossRef]

90. Zhou, J.; Wang, Z.; Zhang, L.; Gu, Y.; Ma, Y.; Li, X. Association of five genetic variations in DNMT1 and DNMT3A with gastric cancer in a Chinese population. Future Oncol. 2018, 14, 1731-1739. [CrossRef]

91. Li, H.; Li, W.; Liu, S.; Zong, S.; Wang, W.; Ren, J.; Li, Q.; Hou, F.; Shi, Q. DNMT1, DNMT3A and DNMT3B Polymorphisms Associated With Gastric Cancer Risk: A Systematic Review and Meta-analysis. EBioMedicine 2016, 13, 125-131. [CrossRef]

92. Neves, M.; Ribeiro, J.; Medeiros, R.; Sousa, H. Genetic polymorphism in DNMTs and gastric cancer: A systematic review and meta-analysis. Porto Biomed. J. 2016, 1, 164-172. [CrossRef]

93. Campbell, P.M.; Szyf, M. Human DNA methyltransferase gene DNMT1 is regulated by the APC pathway evident in a variety of cancers, including colorectal cancer genes have been proposed, a causal downstream agent established. Because previous work implicates DNA methyl-epigenetic. Carcinogenesis 2003, 24, 17-24. [CrossRef]

94. Rubinstein, J.C.; Khan, S.A.; Christison-Lagay, E.R.; Cha, C. APC mutational patterns in gastric adenocarcinoma are enriched for missense variants with associated decreased survival. Genes Chromosom. Cancer 2020, 59, 64-68. [CrossRef] [PubMed]

95. Zhou, X.; Jiao, D.; Dou, M.; Zhang, W.; Hua, H.; Chen, J.; Li, Z.; Li, L.; Han, X. Association of APC gene promoter methylation and the risk of gastric cancer. Medicine 2020, 99, e19828. [CrossRef] [PubMed]

96. Sepulveda, A.R. Helicobacter, Inflammation, and Gastric Cancer. Curr. Pathobiol. Rep. 2013, 1, 9-18. [CrossRef] [PubMed]

97. Beigier-Bompadre, M.; Moos, V.; Belogolova, E.; Allers, K.; Schneider, T.; Churin, Y.; Ignatius, R.; Meyer, T.F.; Aebischer, T. Modulation of the CD4 + T-cell response by helicobacter pylori depends on known virulence factors and bacterial cholesterol and cholesterol $\alpha$-glucoside content. J. Infect. Dis. 2011, 204, 1339-1348. [CrossRef] 
98. Chang, C.C.; Kuo, W.S.; Chen, Y.C.; Perng, C.L.; Lin, H.J.; Ou, Y.H. Fragmentation of CagA reduces hummingbird phenotype induction by helicobactor pylori. PLoS ONE 2016, 11, e0150061. [CrossRef]

99. Ferreira, R.M.; Machado, J.C.; Leite, M.; Carneiro, F.; Figueiredo, C. The number of Helicobacter pylori CagA EPIYA $C$ tyrosine phosphorylation motifs influences the pattern of gastritis and the development of gastric carcinoma. Histopathology 2012, 60, 992-998. [CrossRef]

100. Wu, W.K.K.; Yu, J.; Chan, M.T.V.; To, K.F.; Cheng, A.S.L. Combinatorial epigenetic deregulation by Helicobacter pylori and Epstein-Barr virus infections in gastric tumourigenesis. J. Pathol. 2016, 239, 245-249. [CrossRef]

101. Calcagno, D.Q.; Gigek, C.O.; Chen, E.S.; Burbano, R.R.; Smith, M.D.A.C. DNA and histone methylation in gastric carcinogenesis. World J. Gastroenterol. 2013, 19, 1182-1192. [CrossRef]

102. Fu, D.G. Epigenetic alterations in gastric cancer (Review). Mol. Med. Rep. 2015, 12, 3223-3230. [CrossRef]

103. Rando, O.J. Combinatorial complexity in chromatin structure and function: Revisiting the histone code. Curr. Opin. Genet. Dev. 2012, 22, 148-155. [CrossRef]

104. Ellis, L.; Atadja, P.W.; Johnstone, R.W. Epigenetics in cancer: Targeting chromatin modifications. Mol. Cancer Ther. 2009, 8, 1409-1420. [CrossRef] [PubMed]

105. Du, J.; Johnson, L.M.; Jacobsen, S.E.; Patel, D.J. DNA methylation pathways and their crosstalk with histone methylation. Nat. Rev. Mol. Cell Biol. 2015, 16, 519-532. [CrossRef] [PubMed]

106. Gao, F.; Ji, G.; Gao, Z.; Han, X.; Ye, M.; Yuan, Z.; Luo, H.; Huang, X.; Natarajan, K.; Wang, J.; et al. Direct ChIP-bisulfite sequencing reveals a role of $\mathrm{H} 3 \mathrm{~K} 27 \mathrm{me} 3$ mediating aberrant hypermethylation of promoter CpG islands in cancer cells. Genomics 2014, 103, 204-210. [CrossRef]

107. Viré, E.; Brenner, C.; Deplus, R.; Blanchon, L.; Fraga, M.; Didelot, C.; Morey, L.; Van Eynde, A.; Bernard, D.; Vanderwinden, J.M.; et al. The Polycomb group protein EZH2 directly controls DNA methylation. Nature 2006, 439, 871-874.

108. Park, Y.S.; Jin, M.Y.; Kim, Y.J.; Yook, J.H.; Kim, B.S.; Jang, S.J. The global histone modification pattern correlates with cancer recurrence and overall survival in gastric adenocarcinoma. Ann. Surg. Oncol. 2008, 15, 1968-1976. [CrossRef] [PubMed]

109. Kwon, O.H.; Park, J.L.; Kim, M.; Kim, J.H.; Lee, H.C.; Kim, H.J.; Noh, S.M.; Song, K.S.; Yoo, H.S.; Paik, S.G.; et al. Aberrant up-regulation of LAMB3 and LAMC2 by promoter demethylation in gastric cancer. Biochem. Biophys. Res. Commun. 2011, 406, 539-545. [CrossRef] [PubMed]

110. Wang, Z.; Tang, F.; Qi, G.; Yuan, S.; Zhang, G.; Tang, B.; He, S. KDM5B is overexpressed in gastric cancer and is required for gastric cancer cell proliferation and metastasis. Am. J. Cancer Res. 2015, 5, 87-100.

111. Yang, H.; Liu, Z.; Yuan, C.; Zhao, Y.; Wang, L.; Hu, J.; Xie, D.; Wang, L.; Chen, D. Elevated JMJD1A is a novel predictor for prognosis and a potential therapeutic target for gastric cancer. Int. J. Clin. Exp. Pathol. 2015, 8, 11092-11099.

112. Hu, C.E.; Liu, Y.C.; Zhang, H.D.; Huang, G.J. JMJD2A predicts prognosis and regulates cell growth in human gastric cancer. Biochem. Biophys. Res. Commun. 2014, 449, 1-7. [CrossRef]

113. Matsukawa, Y.; Semba, S.; Kato, H.; Ito, A.; Yanagihara, K.; Yokozaki, H. Expression of the enhancer of zeste homolog 2 is correlated with poor prognosis in human gastric cancer. Cancer Sci. 2006, 97, 484-491. [CrossRef]

114. Fujii, S.; Ochiai, A. Enhancer of zeste homolog 2 downregulates E-cadherin by mediating histone H3 methylation in gastric cancer cells. Cancer Sci. 2008, 99, 738-746. [CrossRef] [PubMed]

115. Casciello, F.; Windloch, K.; Gannon, F.; Lee, J.S. Functional role of G9a histone methyltransferase in cancer. Front. Immunol. 2015, 6. [CrossRef] [PubMed]

116. Zhang, C.; Wei, S.; Hu, J.; Xiong, Z.; Lee, J.H. Upregulated expression of G9a is correlated with poor prognosis of gastric cancer patients. Medicne 2019, 98, e18212. [CrossRef] [PubMed]

117. Lin, X.; Huang, Y.; Zou, Y.; Chen, X.; Ma, X. Depletion of G9a gene induces cell apoptosis in human gastric carcinoma. Oncol. Rep. 2016, 35, 3041-3049. [CrossRef] [PubMed]

118. Yin, C.; Ke, X.; Zhang, R.; Hou, J.; Dong, Z.; Wang, F.; Zhang, K.; Zhong, X.; Yang, L.; Cui, H. G9a promotes cell proliferation and suppresses autophagy in gastric cancer by directly activating mTOR. FASEB J. 2019, 33, 14036-14050. [CrossRef]

119. Estève, P.O.; Hang, G.C.; Smallwood, A.; Feehery, G.R.; Gangisetty, O.; Karpf, A.R.; Carey, M.F.; Pradhan, S. Direct interaction between DNMT1 and G9a coordinates DNA and histone methylation during replication. Genes Dev. 2006, 20, 3089-3103. [CrossRef] 
120. Hervouet, E.; Peixoto, P.; Delage-Mourroux, R.; Boyer-Guittaut, M.; Cartron, P.F. Specific or not specific recruitment of DNMTs for DNA methylation, an epigenetic dilemma. Clin. Epigenet. 2018, 10, 17. [CrossRef]

121. Hu, L.; Zang, M.; Wang, H.-X.; Zhang, B.-G.; Wang, Z.-Q.; Fan, Z.-Y.; Wu, H.; Li, J.-F.; Su, L.-P.; Yan, M.; et al. G9A promotes gastric cancer metastasis by upregulating ITGB3 in a SET domain-independent manner. Cell Death Dis. 2018, 9, 278. [CrossRef]

122. Glozak, M.A.; Sengupta, N.; Zhang, X.; Seto, E. Acetylation and deacetylation of non-histone proteins. Gene 2005, 363, 15-23. [CrossRef]

123. Roth, S.Y.; Denu, J.M.; Allis, C.D. Histone acetyltransferases. Annu. Rev. Biochem. 2001, 70, 81-120. [CrossRef]

124. Schizas, D.; Mastoraki, A.; Naar, L.; Tsilimigras, D.I.; Katsaros, I.; Fragkiadaki, V.; Karachaliou, G.S.; Arkadopoulos, N.; Liakakos, T.; Moris, D. Histone Deacetylases (HDACs) in gastric cancer: An update of their emerging prognostic and therapeutic role. Curr. Med. Chem. 2019, 26. [CrossRef] [PubMed]

125. Li, Y.; Seto, E. HDACs and HDAC inhibitors in cancer development and therapy. Cold Spring Harb. Perspect. Med. 2016, 6, a026831. [CrossRef] [PubMed]

126. Amnekar, R.V.; Khan, S.A.; Rashid, M.; Khade, B.; Thorat, R.; Gera, P.; Shrikhande, S.V.; Smoot, D.T.; Ashktorab, H.; Gupta, S. Histone deacetylase inhibitor pre-treatment enhances the efficacy of DNA-interacting chemotherapeutic drugs in gastric cancer. World J. Gastroenterol. 2020, 26, 598-613. [CrossRef] [PubMed]

127. Ono, S.; Oue, N.; Kuniyasu, H.; Suzuki, T.; Ito, R.; Matsusaki, K.; Ishikawa, T.; Tahara, E.; Yasui, W. Acetylated histone H4 is reduced in human gastric adenomas and carcinomas. J. Exp. Clin. Cancer Res. 2002, 21, 377-382.

128. Sudo, T.; Mimori, K.; Nishida, N.; Kogo, R.; Iwaya, T.; Tanaka, F.; Shibata, K.; Fujita, H.; Shirouzu, K.; Mori, M. Histone deacetylase 1 expression in gastric cancer. Oncol. Rep. 2011, 26, 777-782.

129. Mutze, K.; Langer, R.; Becker, K.; Ott, K.; Novotny, A.; Luber, B.; Hapfelmeier, A.; Göttlicher, M.; Höfler, H.; Keller, G. Histone deacetylase (HDAC) 1 and 2 expression and chemotherapy in gastric cancer. Ann. Surg. Oncol. 2010, 17, 3336-3343. [CrossRef]

130. Noguchi, A.; Kikuchi, K.; Zheng, H.; Takahashi, H.; Miyagi, Y.; Aoki, I.; Takano, Y. SIRT1 expression is associated with a poor prognosis, whereas DBC1 is associated with favorable outcomes in gastric cancer. Cancer Med. 2014, 3, 1553-1561. [CrossRef]

131. Lei, Z.; Tan, I.B.; Das, K.; Deng, N.; Zouridis, H.; Pattison, S.; Chua, C.; Feng, Z.; Guan, Y.K.; Ooi, C.H.; et al. Identification of molecular subtypes of gastric cancer with different responses to PI3-kinase inhibitors and 5-fluorouracil. Gastroenterology 2013, 145, 554-565. [CrossRef]

132. Feng, L.; Pan, M.; Sun, J.; Lu, H.; Shen, Q.; Zhang, S.; Jiang, T.; Liu, L.; Jin, W.; Chen, Y.; et al. Histone deacetylase 3 inhibits expression of PUMA in gastric cancer cells. J. Mol. Med. 2013, 91, 49-58. [CrossRef]

133. Niwa, T.; Toyoda, T.; Tsukamoto, T.; Mori, A.; Tatematsu, M.; Ushijima, T. Prevention of helicobacter pylori-induced gastric cancers in gerbils by a DNA demethylating agent. Cancer Prev. Res. 2013, 6, 263-270. [CrossRef]

134. Yang, W.; Mok, M.T.S.; Li, M.S.M.; Kang, W.; Wang, H.; Chan, A.W.; Chou, J.L.; Chen, J.; Ng, E.K.W.; To, K.F.; et al. Epigenetic silencing of GDF1 disrupts SMAD signaling to reinforce gastric cancer development. Oncogene 2016, 35, 2133-2144. [CrossRef] [PubMed]

135. Shin, D.Y.; Kim, G.Y.; Kim, C.G.; Kim, W.J.; Kang, H.S.; Choi, Y.H. Anti-invasive effects of decitabine, a DNA methyltransferase inhibitor, through tightening of tight junctions and inhibition of matrix metalloproteinase activities in AGS human gastric carcinoma cells. Oncol. Rep. 2012, 28, 1043-1050. [CrossRef] [PubMed]

136. Zouridis, H.; Deng, N.; Ivanova, T.; Zhu, Y.; Wong, B.; Huang, D.; Wu, Y.H.; Wu, Y.; Tan, I.B.; Liem, N.; et al. Methylation subtypes and large-scale epigenetic alterations in gastric cancer. Sci. Transl. Med. 2012, 4, 156ra140. [CrossRef] [PubMed]

137. Hernández-Rosas, F.; Hernández-Oliveras, A.; Flores-Peredo, L.; Rodríguez, G.; Zarain-Herzberg, Á.; Caba, M.; Santiago-Garcia, J. Histone deacetylase inhibitors induce the expression of tumor suppressor genes per1 and per2 in human gastric cancer cells. Oncol. Lett. 2018, 16, 1981-1990. [PubMed]

138. Sun, J.; Piao, J.; Li, N.; Yang, Y.; Kim, K.Y.; Lin, Z. Valproic acid targets HDAC1/2 and HDAC1/PTEN/Akt signalling to inhibit cell proliferation via the induction of autophagy in gastric cancer. FEBS J. 2019, 287, 2118-2133. [CrossRef]

139. Dong, J.; Zheng, N.; Wang, X.; Tang, C.; Yan, P.; Zhou, H.-B.; Huang, J. A novel HDAC6 inhibitor exerts an anti-cancer effect by triggering cell cycle arrest and apoptosis in gastric cancer. Eur. J. Pharmacol. 2018, 828, 67-79. [CrossRef] 
140. Fattahi, S.; Golpour, M.; Amjadi-Moheb, F.; Sharifi-Pasandi, M.; Khodadadi, P.; Pilehchian-Langroudi, M.; Ashrafi, G.H.; Akhavan-Niaki, H. DNA methyltransferases and gastric cancer: Insight into targeted therapy. Epigenomics 2018, 10, 1477-1497. [CrossRef]

141. Xiong, K.; Zhang, H.; Du, Y.; Tian, J.; Ding, S. Identification of HDAC9 as a viable therapeutic target for the treatment of gastric cancer. Exp. Mol. Med. 2019, 51, 100. [CrossRef]

142. Schneider, B.J.; Shah, M.A.; Klute, K.; Ocean, A.; Popa, E.; Altorki, N.; Lieberman, M.; Schreiner, A.; Yantiss, R.; Christos, P.J.; et al. Phase I study of epigenetic priming with azacitidine prior to standard neoadjuvant chemotherapy for patients with resectable gastric and esophageal adenocarcinoma: Evidence of tumor hypomethylation as an indicator of major histopathologic response. Clin. Cancer Res. 2017, 23, 2673-2680. [CrossRef]

143. Yoo, C.; Ryu, M.H.; Na, Y.S.; Ryoo, B.Y.; Lee, C.W.; Kang, Y.K. Vorinostat in combination with capecitabine plus cisplatin as a first-line chemotherapy for patients with metastatic or unresectable gastric cancer: Phase II study and biomarker analysis. Br. J. Cancer 2016, 114, 1185-1190. [CrossRef]

144. Zhou, Z.; Li, H.-Q.; Liu, F. DNA Methyltransferase Inhibitors and their Therapeutic Potential. Curr. Top. Med. Chem. 2018, 18, 2448-2457. [CrossRef] [PubMed]

145. Pirola, L.; Ciesielski, O.; Balcerczyk, A. The Methylation Status of the Epigenome: Its Emerging Role in the Regulation of Tumor Angiogenesis and Tumor Growth, and Potential for Drug Targeting. Cancers 2018, 10, 268. [CrossRef] [PubMed]

146. Qiu, H.; Yashiro, M.; Shinto, O.; Matsuzaki, T.; Hirakawa, K. DNA methyltransferase inhibitor 5-aza-CdR enhances the radiosensitivity of gastric cancer cells. Cancer Sci. 2009, 100, 181-188. [CrossRef]

147. Regel, I.; Merkl, L.; Friedrich, T.; Burgermeister, E.; Zimmermann, W.; Einwächter, H.; Herrmann, K.; Langer, R.; Röcken, R.; Hofheinz, R.; et al. Pan-histone deacetylase inhibitor panobinostat sensitizes gastric cancer cells to anthracyclines via induction of CITED2. Gastroenterology 2012, 143, 99-109. [CrossRef] [PubMed]

148. Zopf, S.; Ocker, M.; Neureiter, D.; Alinger, B.; Gahr, S.; Neurath, M.F.; Di Fazio, P. Inhibition of DNA methyltransferase activity and expression by treatment with the pan-deacetylase inhibitor panobinostat in hepatocellular carcinoma cell lines. BMC Cancer 2012, 12, 386. [CrossRef]

149. Curry, E.; Green, I.; Chapman-Rothe, N.; Shamsaei, E.; Kandil, S.; Cherblanc, F.L.; Payne, L.; Bell, E.; Ganesh, T.; Srimongkolpithak, N.; et al. Dual EZH2 and EHMT2 histone methyltransferase inhibition increases biological efficacy in breast cancer cells. Clin. Epigenet. 2015, 7, 84. [CrossRef]

150. Lou, H.; Pan, H.; Huang, Z.; Wang, Z.; Wang, D.I. Inhibition of G9a promoted 5-fluorouracil (5-FU) induced gastric cancer cell apoptosis: Via ROS/JNK signaling pathway in vitro and in vivo. RSC Adv. 2019, 9, 14662-14669. [CrossRef]

151. Kim, T.W.; Lee, S.Y.; Kim, M.; Cheon, C.; Ko, S.G. Kaempferol induces autophagic cell death via IRE1-JNK-CHOP pathway and inhibition of G9a in gastric cancer cells. Cell Death Dis. 2018, 9, 875. [CrossRef]

152. Castillo-Aguilera, O.; Depreux, P.; Halby, L.; Arimondo, P.B.; Goossens, L. DNA Methylation Targeting: The DNMT/HMT Crosstalk Challenge. Biomolecules 2017, 7, 3. [CrossRef]

153. Wozniak, R.J.; Klimecki, W.T.; Lau, S.S.; Feinstein, Y.; Futscher, B.W. 5-Aza-2'-deoxycytidine-mediated reductions in G9A histone methyltransferase and histone $\mathrm{H} 3 \mathrm{~K} 9$ di-methylation levels are linked to tumor suppressor gene reactivation. Oncogene 2007, 26, 77-90. [CrossRef]

154. Barcena-Varela, M.; Caruso, S.; Llerena, S.; Alvarez-Sola, G.; Uriarte, I.; Latasa, M.U.; Urtasun, R.; Rebouissou, S.; Alvarez, L.; Jimenez, M.; et al. Dual Targeting of Histone Methyltransferase G9a and DNA-Methyltransferase 1 for the Treatment of Experimental Hepatocellular Carcinoma. Hepatology 2019, 69, 587-603. [CrossRef]

155. Yuan, L.W.; Yamashita, H.; Seto, Y. Glucose metabolism in gastric cancer: The cutting-edge. World J. Gastroenterol. 2016, 22, 2046-2059. [CrossRef] [PubMed]

156. Doi, T.; Iwasa, S.; Muro, K.; Satoh, T.; Hironaka, S.; Esaki, T.; Nishina, T.; Hara, H.; Machida, N.; Komatsu, Y.; et al. Phase 1 trial of avelumab (anti-PD-L1) in Japanese patients with advanced solid tumors, including dose expansion in patients with gastric or gastroesophageal junction cancer: The JAVELIN Solid Tumor JPN trial. Gastric Cancer 2019, 22, 817-827. [CrossRef] [PubMed] 
157. Sundar, R.; Huang, K.K.; Qamra, A.; Kim, K.M.; Kim, S.T.; Kang, W.K.; Tan, A.L.K.; Lee, J.; Tan, P. Epigenomic promoter alterations predict for benefit from immune checkpoint inhibition in metastatic gastric cancer. Ann. Oncol. 2019, 30, 424-430. [CrossRef]

158. Lv, D.; Xing, C.; Cao, L.; Zhuo, Y.; Wu, T.; Gao, N. PD-L1 gene promoter methylation represents a potential diagnostic marker in advanced gastric cancer. Oncol. Lett. 2020, 19, 1223-1234. [CrossRef]

159. Deng, R.; Zhang, P.; Liu, W.; Zeng, X.; Ma, X.; Shi, L.; Wang, T.; Yin, Y.; Chang, W.; Zhang, P.; et al. HDAC is indispensable for IFN-gamma-induced B7-H1 expression in gastric cancer. Clin. Epigenet. 2018, 10, 153. [CrossRef] [PubMed]

160. Li, D.; Xiang, S.; Shen, J.; Xiao, M.; Zhao, Y.; Wu, X.; Du, F.; Ji, H.; Li, M.; Zhao, Q.; et al. Comprehensive understanding of B7 family in gastric cancer: Expression profile, association with clinicopathological parameters and downstream targets. Int. J. Biol. Sci. 2020, 16, 568-582. [CrossRef]

161. Qamra, A.; Xing, M.; Padmanabhan, N.; Kwok, J.J.T.; Zhang, S.; Xu, C.; Leong, Y.S.; Lim, A.P.; Tang, Q.; Ooi, W.F.; et al. Epigenomic promoter alterations amplify gene isoform and immunogenic diversity in gastric adenocarcinoma. Cancer Discov. 2017, 7, 630-651. [CrossRef]

162. Wang, H.C.; Chen, C.W.; Yang, C.L.; Tsai, I.M.; Hou, Y.C.; Chen, C.J.; Shan, Y.S. Tumor-associated macrophages promote epigenetic silencing of gelsolin through DNA methyltransferase 1 in gastric cancer cells. Cancer Immunol. Res. 2017, 5, 885-897. [CrossRef]

163. Loo Yau, H.; Ettayebi, I.; De Carvalho, D.D. The Cancer Epigenome: Exploiting Its Vulnerabilities for Immunotherapy. Trends Cell Biol. 2019, 29, 31-43. [CrossRef]

164. Abdelfatah, E.; Yang, S.; Duncan, M.; Ahuja, N.; Taube, J.M. Gastric Adenocarcinomas and Associated Immune Stroma. Gut 2017, 66, 794-801.

165. Zhu, T.; Hu, Z.; Wang, Z.; Ding, H.; Li, R.; Sun, J.; Wang, G. Epigenetically silenced PD-L1 confers drug resistance to anti-PD1 therapy in gastric cardia adenocarcinoma. Int. Immunopharmacol. 2020, 82, 106245. [CrossRef] [PubMed]

166. Olino, K.; Park, T.; Ahuja, N. Exposing Hidden Targets: Combining epigenetic and immunotherapy to overcome cancer resistance. Semin. Cancer Biol. 2020, 1-9. [CrossRef] [PubMed] 